\title{
AN EVALUATION OF DIFFERENT METHODS TO INVESTIGATE ROOT SYSTEM ARCHITECTURE OF URBAN TREES IN SITU; I. GROUND-PENETRATING RADAR
}

\author{
by Alexia Stokes', Thierry Fourcaud', Jiri Hruska², Jan Cermak ${ }^{3}$, Nadezhda \\ Nadyezdhina ${ }^{3}$, Valeriy Nadyezhdin ${ }^{3}$, and Ludek Praus ${ }^{3}$
}

\begin{abstract}
To evaluate the efficiency of ground-penetrating ra$\operatorname{dar}(G P R)$ to map root systems of urban trees in situ, this technique was tested on three trees in an urban environment. After carrying out the extremely rapid GPR tests around the bases of the sample trees, root systems were excavated with an air spade, which produces a supersonic jet of air used to remove soil from roots. Photographs were taken of root system transects for comparison with GPR images. $R$ oot system architecture was then quantified for one pine tree, and a two-dimensional image of the root system was reconstructed using AM A Pmod software. A comparison of actual roots with images hand drawn from the GPR data showed that the technique is reliable for mapping large roots in the horizontal plane only. M ost errors in data from the GPR method were induced when the root systems were manually redrawn, and from roots running parallel to the electromagnetic signal in the vertical plane. These roots could not be identified by GPR. The GPR technique could be considered a valuable nondestructive tool for the arborist, but it still needs development, especially with regard to a software that could reconstruct 3D images of root system architecture from raw data.
\end{abstract}

Key Words. Ground-penetrating radar; root mapping; architecture; air spade; AM APmod.

Tree root systems are often considered a major threat to certain structures in urban environments, especially when growing near building foundations and underground utilities such as gas or sewage pipes (Cermak et al. 1997). I nsurance companies are subject to increasing numbers of claims from householders and private firms whose buildings allegedly suffer subsidence or structural damage from nearby street trees. H owever, an efficient and inexpensive method does not yet exist for mapping tree root systems or for identifying the presence of individual large roots. A recent study examined a new nondestructive technique, $X$-ray computed tomography (Pierret et al. 1999), but this technique is far from being practical enough to be used by the arborist. U sing existing and new technology, as well as knowledge from different scientific disciplines, this paper describes a pilot study to investigate the reliability of one nondestructive method, georadar, for determining the position of individual roots, as well as the architecture of tree root systems in situ in an urban environment. Ground-penetrating radar (georadar, GPR) projects high-frequency impulses of energy into the soil from a portable radar system. Energy is reflected back to the surface when the impulse strikes an interface between soil particles (Figure 1). T his reflected energy is then recorded on a portable computer. The primary use of GPR has been the identification of compacted soil horizons, stone lines, bedrock, and water tables in soil surveys (D oolittle 1987).T he GPR technique is also used by archaeologists for locating buried artifacts. Some of these archaeologists claim that tree roots can also be identified in their GPR images (Cammarano and Piro 1997; Papamarinopoulos et al 1997).

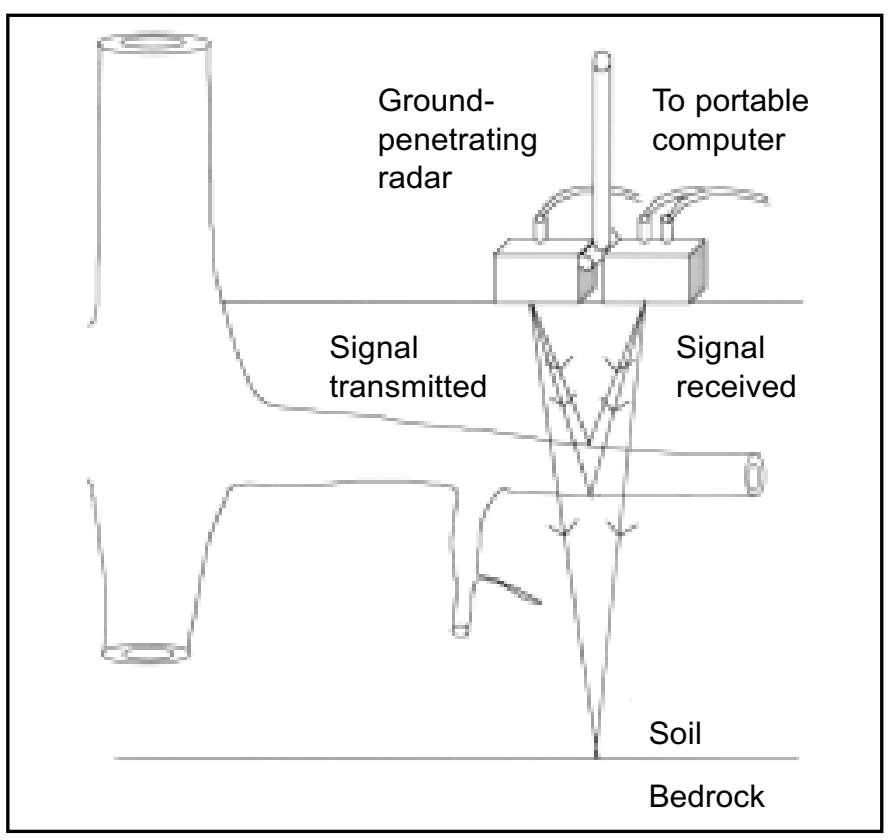

Figure 1. Schematic representation of a portable ground-penetrating radar (GPR) device Tree roots are detected by an electromagnetic signal, as anomalies in the soil, and this information is transmitted in the form of travel time pulses to a portable computer. 
Although mapping tree root systems with GPR has been succesfully used and tested in forest and woodland environments, where soil is relatively homogenous (H ruska et al. 1999; Sustek et al. 1999), doubts still exist about the accuracy of this technique in an urban environment. In towns and cities, soil can be extremely heterogeneous and often contains pipes and cables that interfere with signal processing. This method has been used in an urban environment, although not verified by root excavation (C ermak et al. 2000). Several researchers have also tested this technique, although without much success (C. Lohou, pers. comm.; B.C. N icoll, pers. comm.). These researchers both stated that the main problem with GPR is that it is not possible to tell the difference between underground pipes and stones from roots. H owever, H ruska et al. (1999) claim that their GPR system has a very high resolution and can even distinguish between water-filled pipes and tree roots.

In this study, the reliability of the GPR technique was tested on urban trees, which were subsequently excavated using an air spade ( $R$ izzo and G ross 2000). R oot architecture was then measured and manually digitized (Danjon et al. 1999a, 1999b) to compare two-dimensional root system images with those created by the GPR data.

\section{MATERIALS AND METHODS \\ Experimental Site and Sample Trees}

The experimental site was situated in a garden in the city of Brno, Czech R epublic [latitude $49^{\circ} 12^{\prime}$, longitude $16^{\circ} 39^{\prime}$, altitude $225 \mathrm{~m}$ (738 ft)] on a slight (5\%) west-facing slope. The site was characterized by a hard and deep loessclay soil of quaternary origin with a $20 \%$ mixture of gravel, covered in places by a shallow layer of lighter soil, mixed with bricks and construction rubble (Cermak et al. 2000). Subsoil was composed of sediments of tertiary origin, Pleistocene loess, torton calcareous clays of montmorilonite type with local occurrence of oncoforous sands (Janovsky 1996). R ecent climatic data (monthly means from 1991 through 1996) showed prevailing dry weather in late summer months (H ydrometeorological Institute, Brno).

Three trees were chosen for the evaluation of GPR . $O$ ne solitary pine (Pinus nigra Arn.) and two mountain ash (Sorbus intermedia (Ehrh.) Pers.) trees, which were growing at distances of 6 and $20 \mathrm{~m}$ (19.7 and $65.7 \mathrm{ft}$ ), respectively, from the edge of a 2-m-deep (6.6- $\mathrm{ft}$ ) ditch, where a large two storey building was situated. The two mountain ash trees were growing at a distance of $2.7 \mathrm{~m}$ (8.9 ft) from each other, and thus had interlocking crowns. The smaller mountain ash tree had been damaged by the removal of a 20- $\mathrm{cm}$-wide (7.9-in.) strip of bark along the stem on the east side, resulting in a wound infected by a saprophytic fungus (E xidia glandulosa, Phragmo basidiomycetes).

\section{Ground-Penetrating Radar}

Ground-penetrating radar (GPR) measurements were carried out on root systems using the same method used in previous studies (H ruska et al. 1999; C ermak et al. 2000). The trees were surrounded by a $6 \times 6 \mathrm{~m}(64.6 \times 64.6 \mathrm{ft})$ plot of grass around the pine tree, and a $9 \times 7 \mathrm{~m}(96.9 \times$ $75.3 \mathrm{ft}$ ) plot around the two mountain ash trees. There was a small stump from a shrub growing in the southeast corner of the examined area around the pine, and two other smaller mountain ash trees and one lime (T ilia platyphyllos) tree were growing near the southern edge of the area to be measured around the mountain ash trees. Two small shrubs were also situated close to the northeastern edge of this sampling area. It could therefore be presumed that the GPR signals would detect not only roots of the sample trees but also roots from nearby trees and woody shrubs. This mixture of roots was not an ideal situation for testing GPR on urban tree roots, but it was not possible to find isolated trees whose root systems could be excavated and which could be felled after the experiment.

GPR measurement was performed with a portable signal transmitter and receiver-type pulseEKKO $1000 \mathrm{~A}^{\mathrm{m}}$ GPR system (Sensors \& Software Inc., M ississauga, O ntario) using a signal frequency of $450 \mathrm{M} \mathrm{Hz}$, which allows horizontal as well as vertical distances to be distinguished with a precision of $5 \mathrm{~cm}$ (2 in.). R oots with a diameter greater than $2 \mathrm{~cm}(0.8 \mathrm{in}$.) can be identified down to a depth of $2.5 \mathrm{~m}(8.2 \mathrm{ft})$. The instrument was gradually moved over the soil surface along specified grid lines, and vertical "slices" of soil were measured (Figure 1 ). The profile step was $0.05 \mathrm{~m}(0.2 \mathrm{ft})$ along lines $0.25 \mathrm{~m}$ $(0.8 \mathrm{ft})$ apart in two perpendicular directions. In total, 301 $\mathrm{m}(987 \mathrm{ft}$ ) of lines were scanned, giving 6,160 records for pine, and $476 \mathrm{~m}(1,562 \mathrm{ft})$ with 9,504 records for the two mountain ash trees together.

The effective velocity needed to transfer the radar signal into the soil was $v=0.085 \mathrm{~m} \mathrm{~ns}^{1}$, which was estimated through direct measurements of layer velocities at the site and corresponds to that of loess-clay soil.T he file of collected data was then processed and evaluated with the software packages EKKO Tools 4.23 and R eflex 4 (K.J. Sandmeier, K arlsruhe, Germany). Both packages are standard geophysical, namely georadar and seismic, signalprocessing packages. W ith this system of processing, it is possible to evaluate the most interesting features of the cross-section under study and suppress unnecessary informa- 
tion (H ruska et al. 1999; Sustek et al. 1999). O bjects such as stones, cables, and pipes in the soil can be discriminated against using this software. Selected images of root systems (vertical and horizontal views) derived from the measured data were displayed on the computer screen (Figure 2) and then redraw $n$ by hand.

\section{Air-Spade Excavation}

$R$ oots were excavated using an air spade (Air-Spade Technology,Verona, PA, model 150/90), which converts the energy of compressed air into digging power using an ultrasonic thin air stream with a velocity of $2 \mathrm{M}$ achs. The air spade was connected to an Ingersoll- $R$ and compressor that could output a force of $6 \times 10^{5} \mathrm{~Pa}$ at a velocity of 0.8 $\mathrm{m}^{3} \mathrm{~s}^{-1}$. O nly the northern half the root system [18 $\mathrm{m}^{2}$ (194 $\left.\mathrm{ft}^{2}\right)$ ] of the pine tree was excavated, to a depth of 0.5 to $1 \mathrm{~m}$ (1.6 to $3.3 \mathrm{ft}$ ), due to a shortage of time.Two perpendicular $1 \mathrm{~m}^{2}\left(10.8 \mathrm{ft}^{2}\right)$ transects (south-north and east-west) were also excavated to a depth of $0.5 \mathrm{~m}$ close to the trunk in both Sorbus trees. The exact location of building rubble, such as cables and pipes, was also noted. Excavated root systems were marked by a $1 \times 1 \mathrm{~m}$ network made of string, and each transect was then photographed to obtain an accurate optical image that could be compared to the images obtained by GPR .

\section{Digitizing of Root System}

To produce highly accurate images of root system architecture, which would complement the photographs taken and allow an easier comparison with images of root systems obtained from the GPR data, the root system of the pine tree was manually digitized.T he main reason for digitizing the root sys tems was that the photographs were taken while standing at a certain height above the root system but without any accurate positioning of the camera above each quadrant. Therefore, root size cannot accurately be de- termined from these photographs because they may have been taken at an angle. Digitized images also provide quantitative data on root size, orientation, and branching pattern. These data are then used for later processing with software that reconstructs 3D images. The manual digitizing process involves the diameter and orientation from due north being measured every $10 \mathrm{~cm}$ (4 in.), along each lateral root and daughter branch $>1 \mathrm{~cm}(0.4 \mathrm{in}$.), to a depth of $25 \mathrm{~cm}$ (9.8 in.). Data were then used as input to the software AM APmod (CAM AP, CIR AD, France).

The software AM APmod was used to analyze data, and it can handle branched structure at several scales: root segments, whole roots, and whole root systems. Threedimensional graphical reconstruction is also possible and is normally used for checking data (Godin et al. 1997; D anjon et al. 1999a, 1999b). H owever, in this case, only a $2 \mathrm{D}$ image was necessary to compare the surface roots with the GPR images.

\section{RESULTS}

The GPR technique was rapid, with $99 \mathrm{~m}^{2}\left(1,066 \mathrm{ft}^{2}\right)$ of ground mapped in about 12 hours. 0 ne week was then needed to analyze the data. Excavation of root systems was carried out in only 3 days, despite the hard texture of

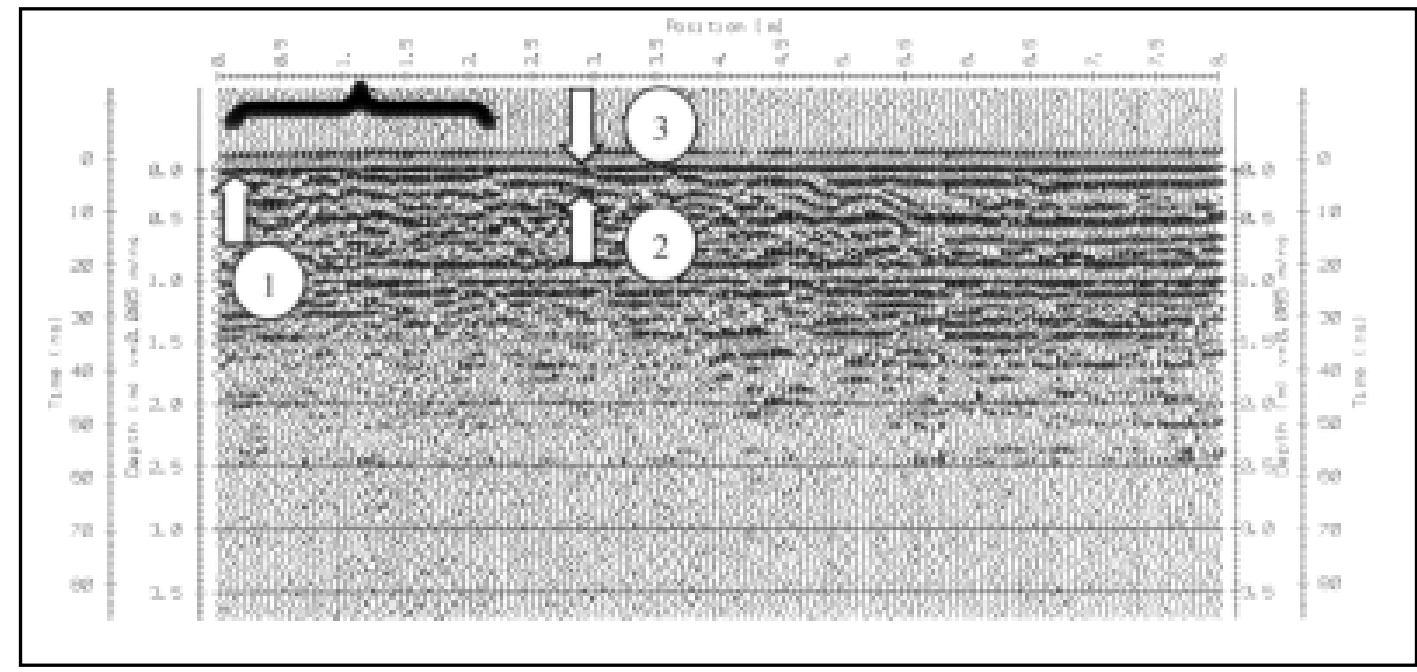

Figure 2. Typical ground-penetrating radar (GPR) profile at the experimental site The $X$ axis corresponds to soil depth, and theY axis to the position of the GPR on the soil surface The scan consists of a series of reflections-portions of signal reflected from the ground by various objects such as soil strata surfaces, which are usually continuous or near horizontal lines [eg., the soil surface (indicated by black bracket) and local bodies (indicated by white arrows)]. Individual roots can be detected by anomalies in the signal diffraction, these anomalies being distinguished by their more or less pronounced hyperbolic shape This shape is caused by the signal scattering on the target object, which in this case corresponds to individual roots. Arrow number 1 indicates the base of a lateral root, and arrows 2 and 3, a branching or crossing-over of the same

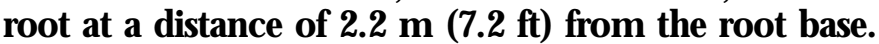


the soil, especially around the mountain ash trees. The slowest part of the excavation was due to the removal of stones in the soil by hand, which was necessary for every half hour of excavation with the air spade.

The GPR images, drawn by hand from the data, suggested that the pine root system occupied practically all the area examined and that roots extended farther than the studied transects, which is in agreement with observations when the root system was excavated (Figures $3 a$ and 4a). The data illustrated that the trunk was positioned centrally within the root system, which was itself circular in shape. As the roots were excavated to a depth of 0.5 to $1 \mathrm{~m} \mathrm{(1.6} \mathrm{to} 3.3 \mathrm{ft}$ ), it could be seen that the root system consisted of two tiers, with most lateral roots in the top $20 \mathrm{~cm}$ (7.9 in.) of soil. Between a depth of 20 and $80 \mathrm{~cm}$ (31.5 in.), no lateral roots $>2 \mathrm{~cm}$ (0.8 in.) in diameter were found (Figure $3 \mathrm{~b}$ ). W hen the GPR images of the pine root system in the vertical plane (Figure $4 \mathrm{~b}$ ) were compared with field observations (Figure $3 \mathrm{~b}$ ), no similarities in root architecture were found.

The image of the pine root system reconstructed by AM APmod (Figure 5) was compared to that obtained by GPR (Figure 4a). Two-dimensional images of the root system in the horizontal plane only were compared (Figures $6 a, 6 b$, and $6 c)$. A reasonable likeness existed between the images with regard to the large lateral roots, except for the absence of one major lateral root that had not been captured on the GPR image (Figure 4a). However, many smaller roots existed on the GPR image that were not present on the image of the reconstructed root system and vice versa. These smaller roots on the GPR image may have been roots growing deeper than $20 \mathrm{~cm}$ (7.9 in.), which are not discriminated against in the horizontal plane. It was unlikely that these objects were building rubble such as cables and pipes, because such objects were found and mapped during the root system excavation, yet were not perceived in the GPR root system images. It may be possible that stones were mistaken for roots, but also unlikely, because stones can be discriminated against due to their shape and density. It was, however, impossible to obtain the true root system architecture from the GPR data because GPR was unable to distinguish from crossing-over of roots and branching. Very few second- and third-order lateral roots were present in the horizontal plane (i.e., there was little branching), yet the GPR data suggest that a high amount of branching was present in the pine root system.

The root systems of both mountain ash trees were also mapped using the GPR technique (Figure 7), and although the root systems were excavated, they were not digitized due to lack of time. However, from the photo-
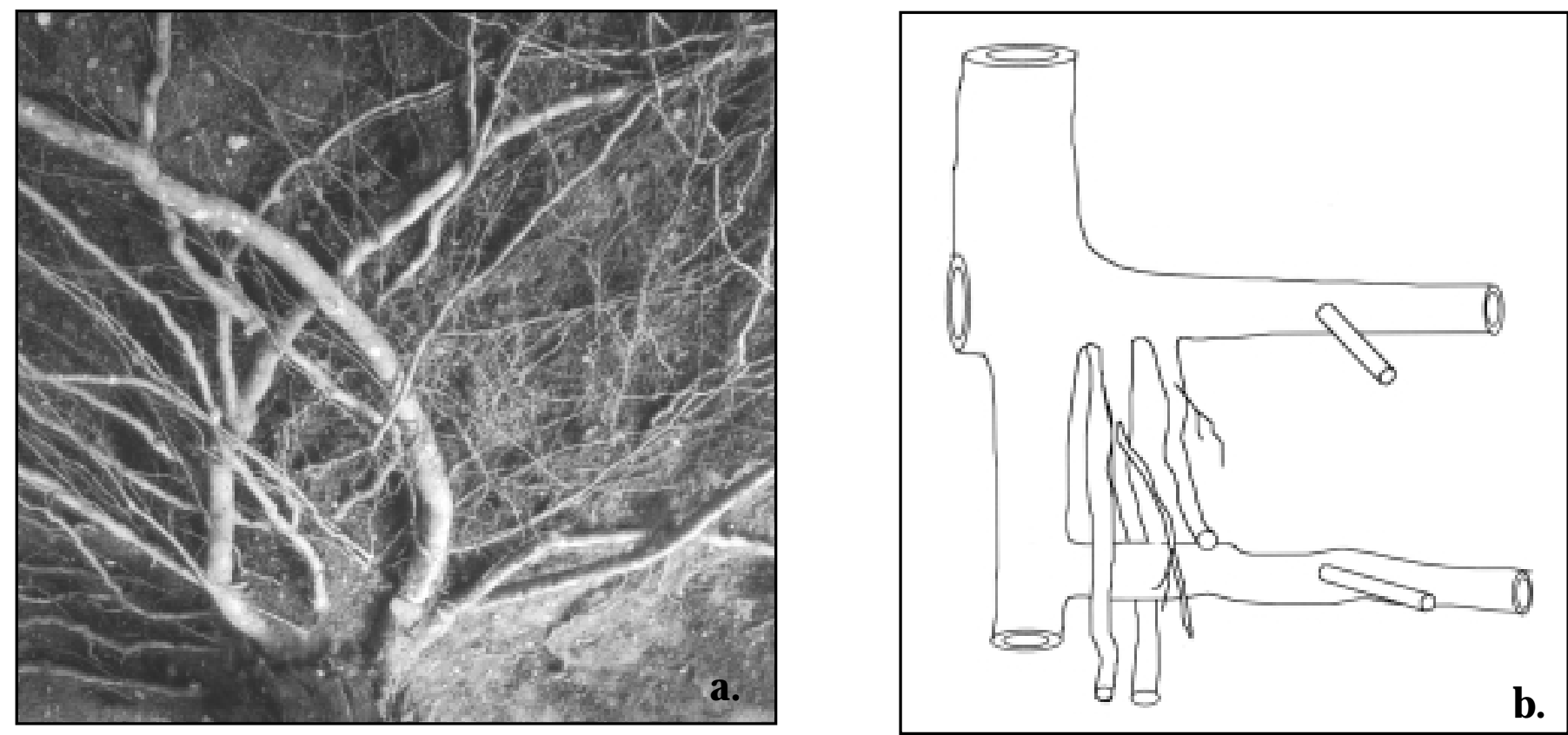

Figure 3. (a) Photograph of an excavated Pinus nigra root system in the horizontal plane and (b) a schematic illustration of the root system in the vertical plane. A photograph is not available due to the difficulty in obtaining a clear photograph in this plane. The schematic illustration shows that lateral roots were abundant in the top $20 \mathrm{~cm}$ (7.9 in.) of soil, and then again at a depth of $80 \mathrm{~cm}$ (31.4 in.). Between these two distances, no lateral roots were found; however, vertical roots were present. 
graphs taken of each transect, it can again be seen that large roots are identifiable using GPR, but that smaller root position and root architecture is not accurate (Figures $8 \mathrm{a}$ and $8 \mathrm{~b}$ ). $\mathrm{R}$ oot density appeared to be much higher in both mountain ash trees compared to the pine tree, especially with regard to roots $<2 \mathrm{~cm}$ ( $0.08 \mathrm{in}$.) in diameter. The root systems of both trees did not overlap, nor did roots of the two trees fuse, which was clear from both the GPR images and the photographs, as well as field observations (Figures 8a and 8b).

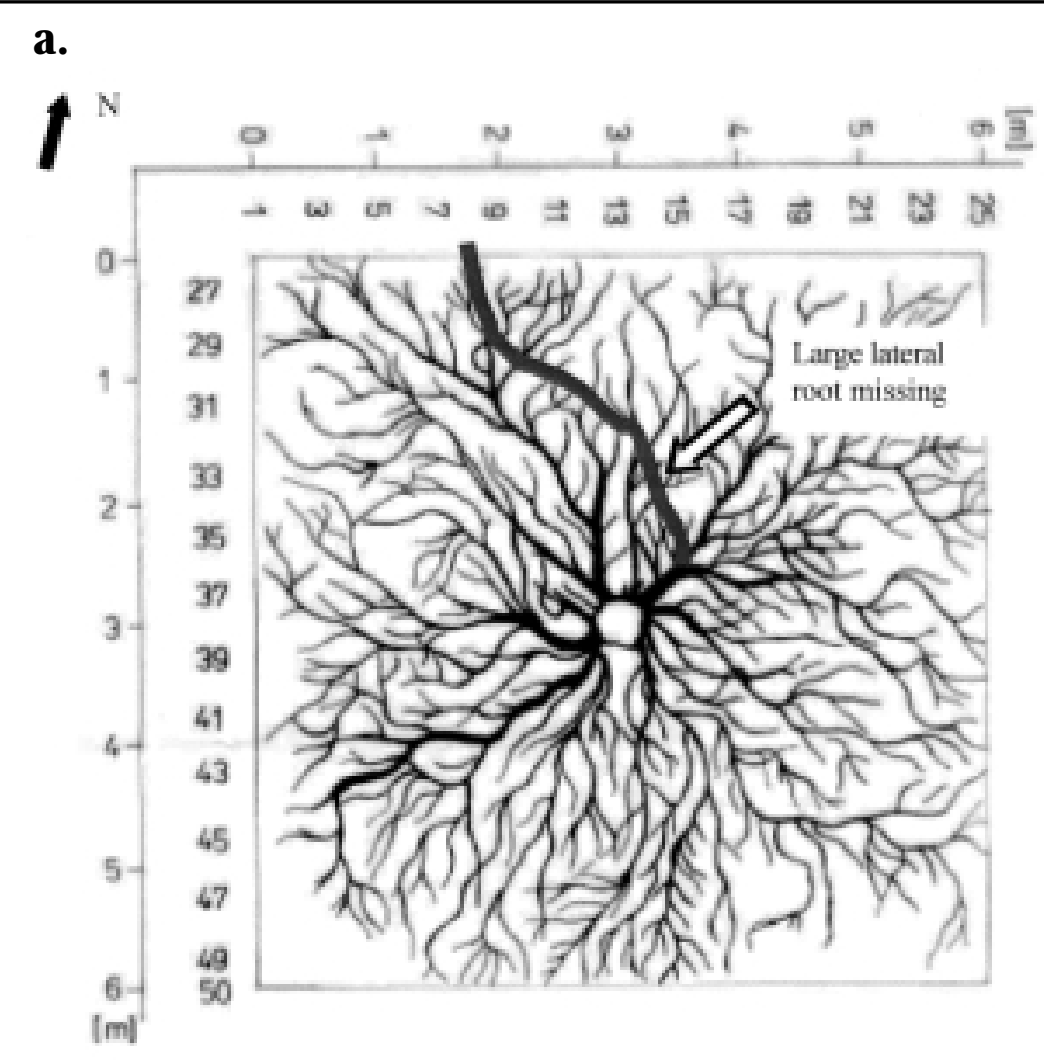

b.

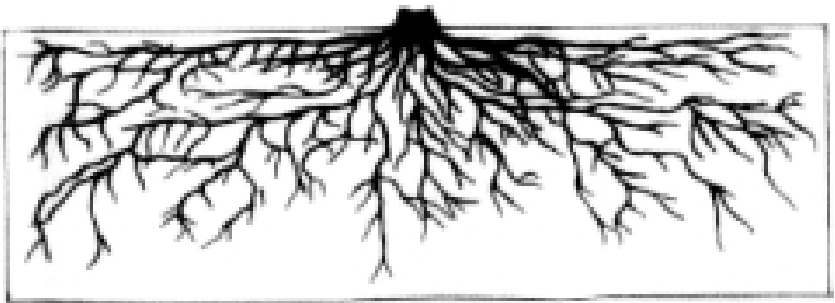

Figure 4. (a) Ground plan view of the Pinus nigra root system, redrawn from the ground-penetrating radar data. One major lateral root has not been detected by the GPR system. (b) Vertical view of the same root system drawn to the same scale. The GPR image of roots in the vertical plane (b) suggests that lateral roots were present at depths of 0 to $100 \mathrm{~cm}(0$ to 39.3 in.); however, this was not the case in reality (Figure 3b).

\section{DISCUSSION}

The GPR technique was relatively easy and rapid to use in the field, provided that an experienced user manipulates the portable radar device and analyzes the data. D ata evaluation takes a considerably longer time. Potential interference from building rubble, pipes, and cables could be distinguished from the tree roots because these objects were found and noted during the excavation but were not included in the analysis of GPR data. A side from the inevitable errors produced by manually redrawing root systems (Sustek et al. 1999), several problems exist with the technique and, in the horizontal plane, are concerned with the accuracy of root size and root system architecture. Although large roots could easily be identified using GPR , smaller roots [ $<20 \mathrm{~mm}$ (0.8 in.) in diameter] could not, nor could the GPR distinguish between root branching and two roots crossing over each other. M ore thin roots were seen to be connected to the main root system in the GPR images of pine than was actually the case. $\mathrm{H}$ owever, when the roots were digitized, only lateral roots and their daughter branches could be analyzed with AMAPmod; therefore, much information was lost. Extra roots may appear in the GPR images because data analysis is unable to discriminate against roots at a certain depth; therefore, all roots between 20 and $100 \mathrm{~cm}$ (7.8 and 39.3 in.) were present in the images of roots in the horizontal plane.

The GPR technique failed to provide useful information when data in the vertical plane were analyzed. GPR images in the vertical plane did not correspond at all to photographs and field observations taken for the pine tree. Although mountain ash root systems were not fully excavated, it can be assumed that GPR data were not accurate for these roots either. The problem with the technique in the vertical plane is that the radar signal cannot identify objects running parallel to the electromagnetic waves transmitted.

It may be possible to use GPR as a tool for tree diagnostics, with the possibility even of determining the healthiness of roots, by quantifying their internal water content, as suggested by H ruska et al. (1999). H owever, much more research and calibrating of species with 


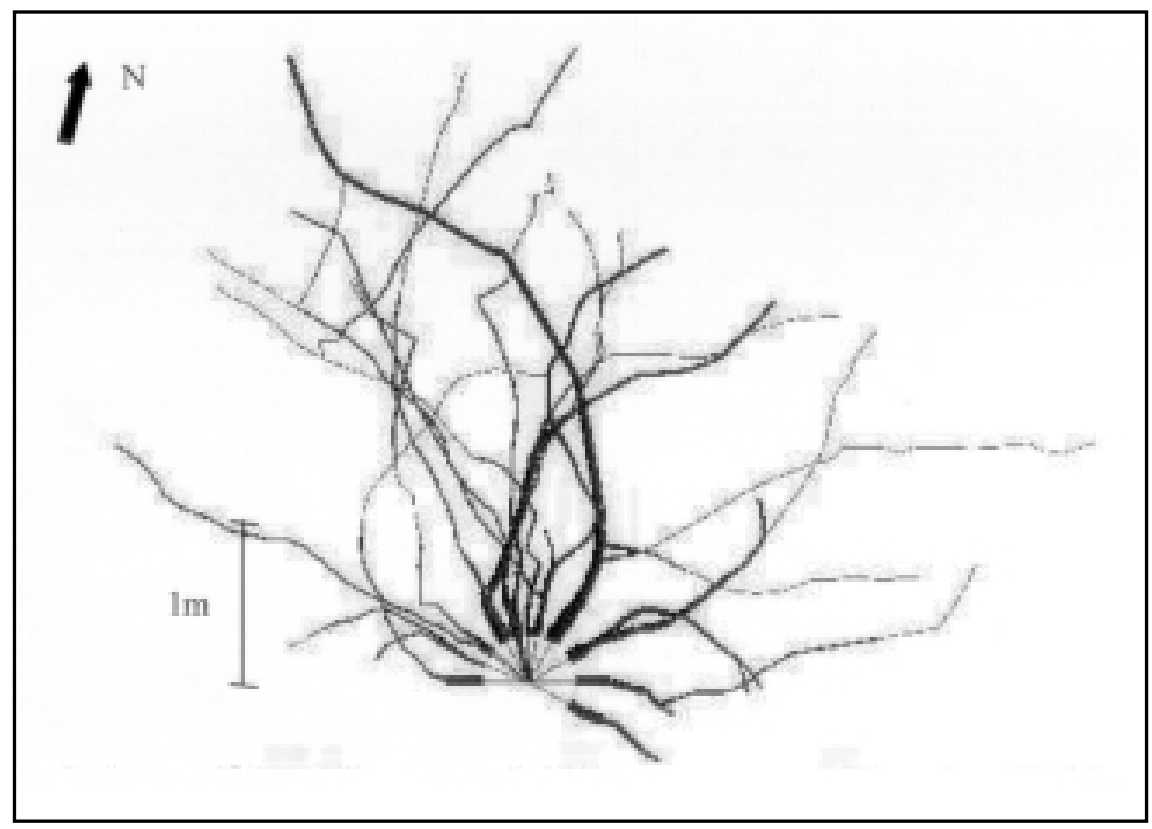

Figure 5. Two-dimensional reconstruction of the Pinus nigra root sys tem (only the northern half of the root system shown) derived from manually digitized architecture data and redrawn using AMAPmod software

a.

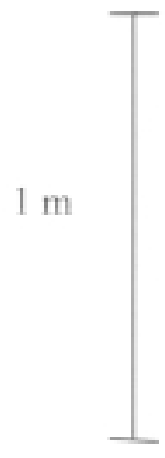

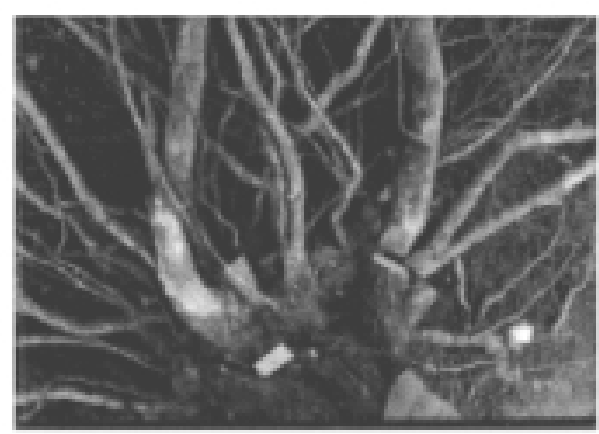

b.

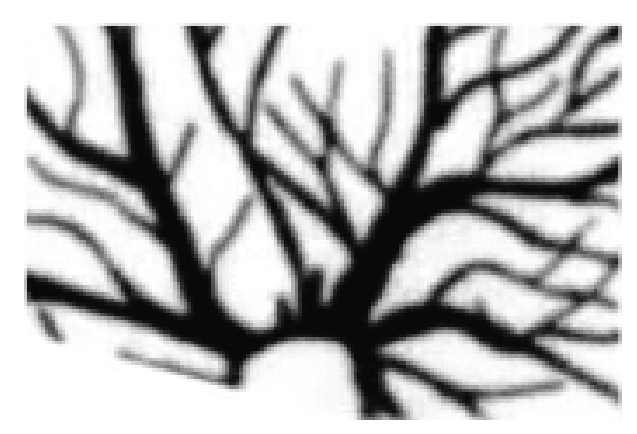

C.

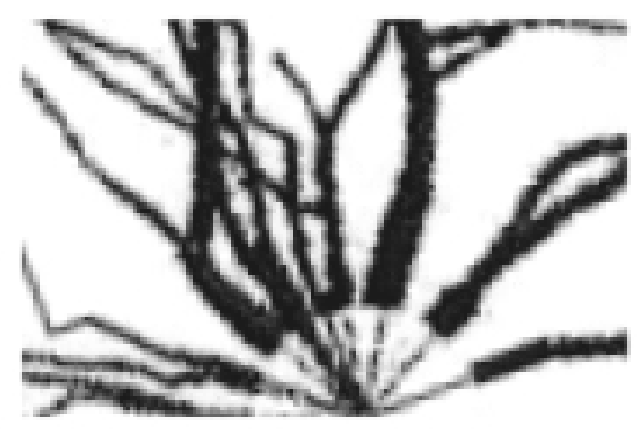

Figure 6. Comparison of one $1 \mathrm{~m}^{2}\left(10.8 \mathrm{ft}^{2}\right)$ transect from the root system of Pinus nigra, using images from (a) photograph, (b) GPR data, and (c) 2D reconstruction derived from digitized architecture data. The large lateral roots appear to be detected by GPR, as can be seen from both the photograph and the 2D digitized image. 
root health would be needed. As a first step, software should be created that could model root system architecture us ing GPR data. This software could consider the laws governing tree root architecture, structure, and function for a given species type (e.g., conifer or broadleaf) and could be used to reconstruct the root system instead of it having to be redrawn by hand from the data (Jourdan and R ey 1997; Blaise et al. 2000). A candidate for such software is AM APmod, which is used to reconstruct $3 D$ images from raw data. AMAPmod is simple to use and not only provides 3D images, but it can be used to analyze data using statistical functions. 0 ther techniques as well may be used in conjunction with such a software; for example, a stereological proce-

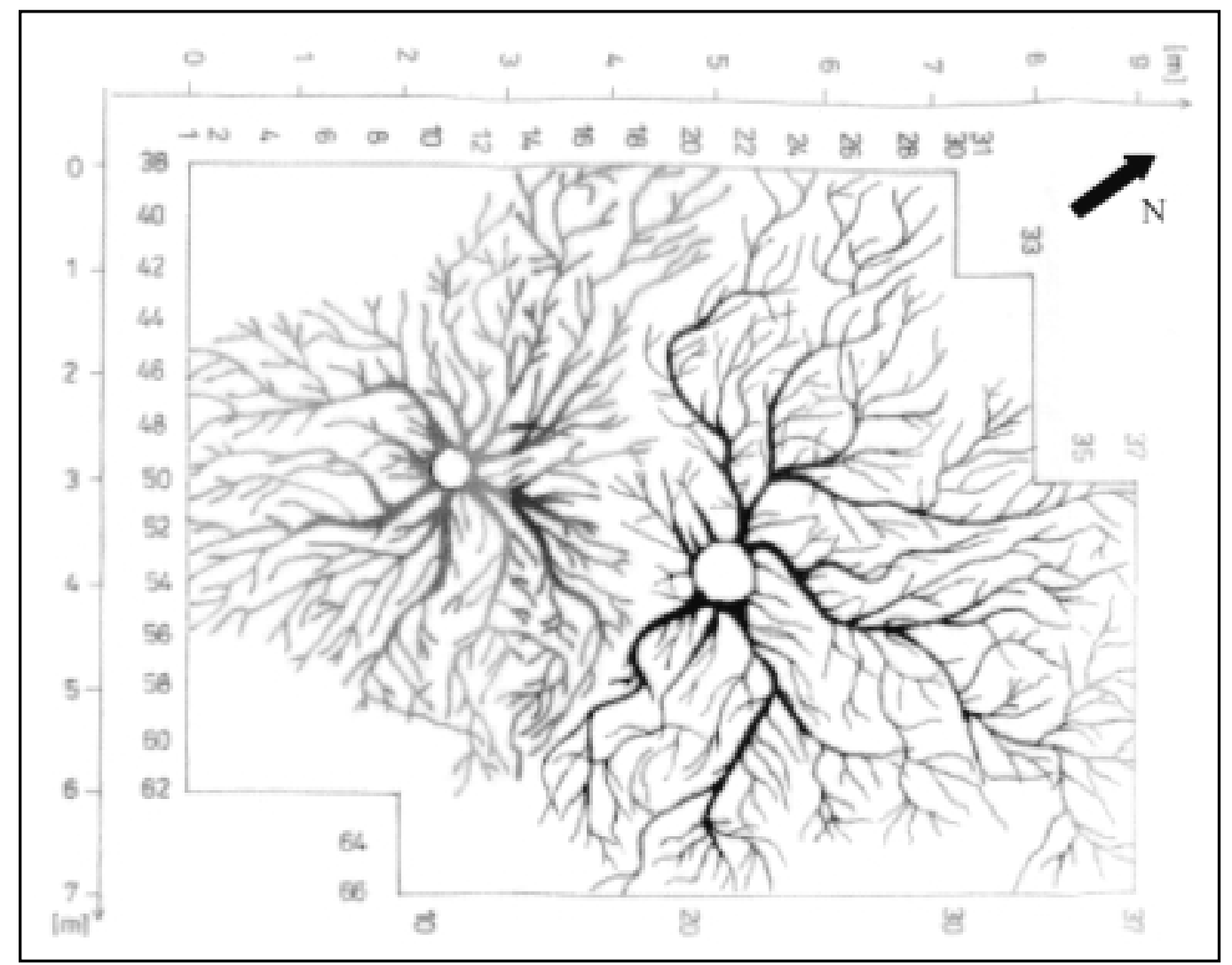

Figure 7. Ground plan view of both Sorbus intermedia root systems, redrawn from the ground-penetrating radar data. The GPR image suggests that root systems do not overlap or fuse with each other. dure has recently been used

to nondestructively estimate root architecture of the grass A gropyron cristatum, which had been grown in a transparent medium (Wulfsohn et al. 1999).

The GPR technique is not cheap, but it may be worthwhile to use on valuable trees or trees in delicate situations where excavation is not possible, such as trees growing near pavements, roads, buildings, on unstable slopes, and possibly also in rapid tree screening schemes. Further development of this technique is possible, and huge advances in the software could be made in order to process root architecture data faster and more accurately. W ith such software and better object resolution, GPR could one day be considered as a useful, nondestructive, rapid technique for assessing root position, root system architecture, and in the long term, root health.

\section{LITERATURE CITED}

Blaise, F., T. Fourcaud, A. Stokes, and P. R effye. 2000. A model simulating interactions between plant shoot and root architecture in a non-homogeneous environment, pp 195207. In Stokes, A. (Ed.). The Supporting R oots of Trees and Woody Plants: Form, Function and Physiology. D evelopments in Plant and Soil Sciences Vol. 87, Kluwer Academic Publishers, D ordrecht, $T$ he $\mathrm{N}$ etherlands.

C ammarano, F., and S. Piro. 1997. A pplication of GPR method to locate and reconstruct archeological structures in the $\mathrm{S}$. Cecilia Basilica (R oma, Italy). In Electric, Magnetic and Electromagnetic $\mathrm{M}$ ethods A pplied to $\mathrm{C}$ ultural $\mathrm{H}$ eritage. 1st International Workshop, $\mathrm{O}$ stuni, I taly.

Cermak, J., J. H ruska, M. M artinkova, T. K rejzar, S. Sustek, N. $\mathrm{N}$ adezhdina, and F. Tatarinov. 1997. O $\mathrm{n}$ the situation of large trees and their impact on constructions at the public baths Zabrdovice (in Czech). R esearch R eport of the Institute of Forest Ecology, Mendel's U niversity of Agriculture and Forestry, Brno, for the Municipal Authorities, Brno, Czech R epublic. 49 pp.

Cermak, J., J. H ruska, M. M artinkova, and A. Prax. 2000. City tree roots and survival near houses analyzed using sap flow and ground penetrating radar technique. Plant Soil 219:103-116.

D anjon, F., D. Bert, C. Godin, and P.Trichet. 1999a. Structural root architecture of 5-year-old Pinus pinaster measured by 3D digitising and analysed with AM A Pmod. Plant Soil 217:49-63.

Danjon, F., H . Sinoquet, C. Godin, F. Colin, and M . D rexhage. 1999b. Characterisation of structural tree root architecture using 3D digitising and A M A Pmod software. Plant Soil 211:241-258. 
a.

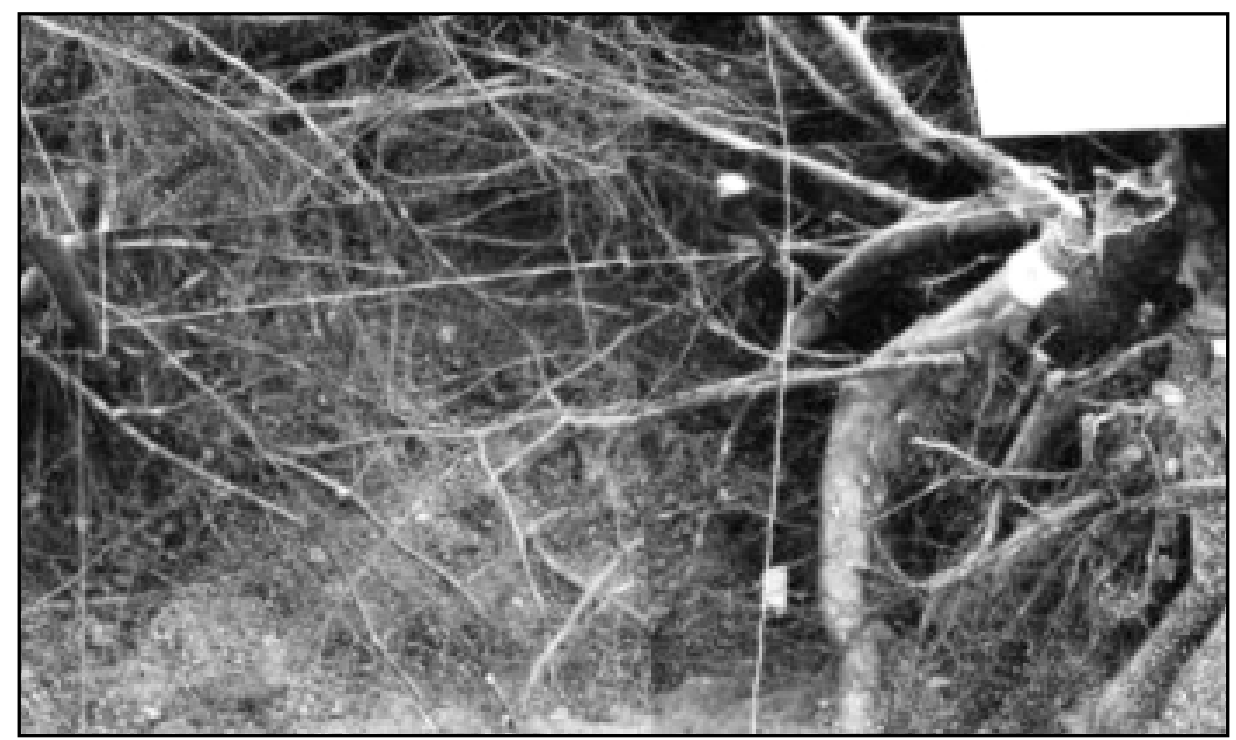

b.

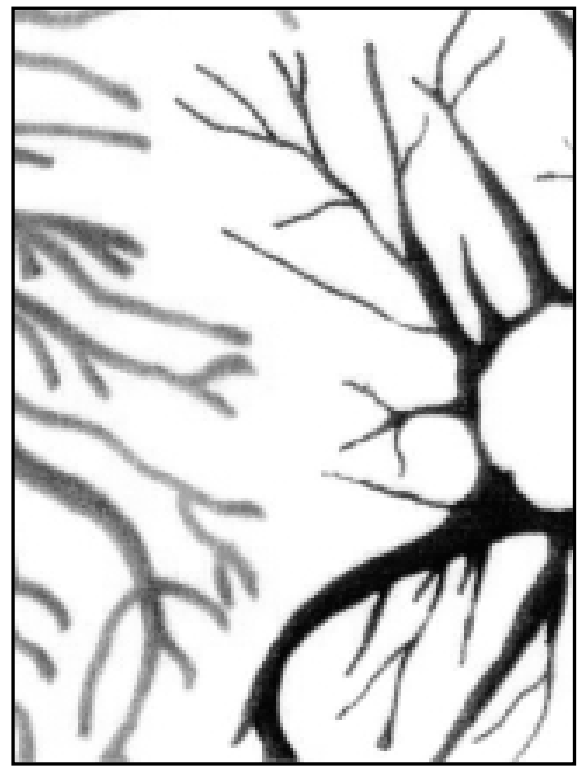

Figure 8. (a) Photograph of two transects taken from near the trunk of one Sorbus intermedia root system. The large lateral roots can be identified in (b), the image redrawn from the GPR data, as well as the lack of roots and root fusion between the two neighboring root systems.

D oolittle, J.A. 1987. U sing ground-penetrating radar to increase the quality and efficiency of soil surveys. In R eybold,W.U., and G.W. Peterson (Eds.). Soil Survey Techniques, SSSA Special Publication N 0. 20. Soil Science Society of A merica, M adison, W I.

Godin, C., E. Costes, and Y. Caraglio. 1997. Exploring plant topological structure with the AMAPmod software: An outline. Silva Fenn. 31:355-366.

H ruska, J., J. C ermak, and S. Sustek. 1999 M apping of tree root systems by means of the ground penetrating radar. Tree Physiol. 19:125-130.

Janovsky, J. 1996. Engineering-geological assessment of the situation at the Skroupova street (in C zech). For M unicipal Authorities of the City of Brno. Environmental Section. Brno, C zech R epublic. $60 \mathrm{pp}$.

Jourdan, C., and H. R ey. 1997. M odelling and simulation of the architecture and development of the oil-palm (Elaeis guineensis Jacq) root system. I. The model. Plant Soil 190:217-233.

Papamarinopoulos, St. P., M . Papai oannou, and P. Stefanopoulos. 1997. Explanation of a religious miracle at a Byzantine Church with geophysical methods at South Greece. In Electromagnetic M ethods A pplied to C ultural H eritage. 1st International. Workshop, 0 stuni, Italy.

Pierret, A.,Y. C apowiez, C. J. M oran, and A. K retzschmar. 1999. $X$-ray computed tomography to quantify tree rooting spatial distributions. Geoderma 90:307-326.
R izzo, D.M ., and R . Gross. 2000. Distribution of A rmillaria on pear root systems and a comparison of root excavation techniques, pp 305-311. In Stokes, A. (Ed.).T he Supporting R oots of Trees and Woody Plants: Form, Function and Physiology. D evelopments in Plant and Soil SciencesVol. 87, K luwer A cademic Publishers, D ordrecht, the $\mathrm{N}$ etherlands.

Sustek, S., J. H ruska, M. Druckmuller, and T. M ichalek. 1999 $R$ oot surfaces in the large oak tree estimated by image analysis of the map obtained by the ground penetrating radar. J. For. Sci. 45:139-143.

Wulfsohn, D., J.R . N yengaard, H .G. Gundersen, A.J. C utler, and T.M. Squires. 1999. N on-destructive, stereological estimation of plant root lengths, branching pattern and diameter distribution. Plant Soil 214:15-26.

Acknowledgments. This study was funded by the John Z. D uling G rant Program (International Society of A rboriculture).

1 * L aboratoire de $R$ heologie du $B$ ois de $B$ ordeaux

(M ixed U nit: U niversité B ordeaux I/ IN R A / C N R S/

CIRAD )

$D$ omaine de I'H ermitage, B.P. 10

33610 C estas $G$ az inet

F rance

stokes@Irbb3.pierroton.inra.fr 
${ }^{2} \mathrm{G}$ eneral $\mathrm{G}$ eophysics $\mathrm{D}$ ivision

$G$ eofyzika Inc.

Jecna 29a, 61246 B rno

C zech R epublic

hruska@ geofyzika.z

${ }^{3} \mathrm{~F}$ aculty of $\mathrm{F}$ orestry and W ood Technology

$M$ endel $U$ niversity of $A$ griculture and $F$ orestry

$Z$ emedelska 3, 61300 B rno

C zech R epublic

cermak@ mendelu.z

\section{"C orresponding author}

Résumé. Dans le but d'évaluer l'efficacité du radar de pénétration dans le sol pour cartographier in situ le système racinaire d'arbres ornementaux, cette technique a été testée avec trois arbres localisés dans un environnement urbain. A près avoir mené le test avec le radar de façon extrêmement rapide autour de la base des arbres, le système racinaire a été dégagé avec un Air Spade, un appareil qui produit un jet supersonique d'air pour enlever le sol autour des racines. D es photos de sections transversales du système racinaire ont été prises afin de les comparer avec les images provenant du radar. L'architecture du système racinaire a par la suite été quantifiée pour un pin, et une image bidimensionnelle du système racinaire refaite à partir du logiciel AMAPmod. Une comparaison entre le système racinaire réel et les images faites à la main à partir des données du radar ont démontré que cette technique était fiable seulement pour la cartographie des grosses racines, et sur un plan horizontal uniquement. La plupart des erreurs dans les données avec la méthode du radar ont été faites lorsque le système racinaire a été redessiné manuellement, et aussi lorsque des racines couraient parallèlement au signal électromagnétique selon un plan vertical. Ces racines ne pouvaient alors être identifiées avec le radar. La technique du radar de pénétration dans le sol peut être considéré comme un outil non destructeur valable pour l'arboriculteur, mais elle nécessite encore des améliorations, plus spécifiquement au niveau du logiciel pour reconstruire une image 3-D de l'architecture du système racinaire à partir des données brutes.

Z usammenfassung. U m die Effektivität von Bodenradar (GPR) bei der Erstellung von Wurzelkatastern in Großstädten in situ zu bewerten, wurde diese Technik an drei Bäumen in einer $\mathrm{G}$ roßstadt getestet. $N$ ach A usführung des extrem schnellen $R$ adartests an den Probebäumen, wurden die Wurzelsysteme mit einem Air Spade (Luftspaten) ausgegraben, wobei durch einen superfeinen Luftstrom die Erde von den Wurzeln geblasen wurde. Das Wurzelsystem wurde fotografiert, um mit den $R$ adaraufnahmen verglichen zu werden. Für eine Kiefer wurde die Wurzelarchitektur quantifiziert und mit Hilfe von AM APmod Software ein zweidimensionales Image von dem Wurzelsystem erzeugt. Ein Vergleich zwischen den tatsächlichen Wurzeln und den Handzeichnungen nach den $R$ adaraufnahmen zeigte, dass diese Technik für die horizontale Erfassung von Wurzeln zuverlässig angewendet werden kann. Die meisten Fehler entstehen bei der manuellen $D$ arstellung der Wurzeln und bei vertikal verlaufenden Wurzeln, die entlang des elektromagnetischen Signals verlaufen. Diese Wurzeln können nicht durch GPR dargestellt werden. Die GPR - Technik kann ein nützlichesWerkzeug für den Arboristen sein, aber es besteht noch Entwicklungsbedarf, besonders bei einer Software, die fehlerfrei in 3D darstellen kann.

Resumen. Con el fin de evaluar la eficiencia de penetración del radar del suelo (GPR ) para mapear sistemas de raíces de los árboles urbanos in situ, se probó esta técnica en tres árboles en un ambiente urbano. Después de llevar a cabo las pruebas rápidamente con GPR alrededor de la base de los árboles de muestra, los sistemas de rá́ces fueron excavados con el Air Spade, el cual produce una inyección supersónica de aire, usado para remover el suelo de las raíces. Se tomaron fotografías de los transectos de las rá́ces, para comparar con las imágenes del GPR . Se cuantificó entonces el sistema arquitectónico de las raíces para un árbol de pino, y una imagen bidimensional del sistema de raíces utilizando el software AM APmod. La comparación de las raíces reales con imágenes de los datos del GPR mostraron que la técnica es aplicable para mapear grandes rá́ces en un plano horizontal solamente. La mayoría de los errores en los datos del método GPR fueron inducidos cuando los sistemas de ráces fueron manualmente redibujados, y de las raíces que van paralelas a la señal electromagnética en el plano vertical. Estas raíces no pueden ser identificadas por el GPR . La técnica GPR puede ser considerada como una valiosa herramienta no destructiva para el arborista. Pero aún necesita desarrollo, especialmente hacia un software que pueda reconstruir imágenes en 3 dimensiones de la arquitectura del sistema de ráces, a partir de los datos tomados. 